Journal homepage: http://www.journalijar.com
Journal DOI: 10.21474/IJAR01

RESEARCH ARTICLE

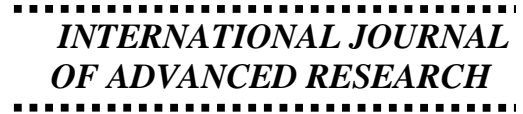

(1)

\title{
COMPLIANCE REGARDING LIFE STYLE MODIFICATIONS IN PREVENTING COMPLICATIONS AMONG HYPERTENSIVE PATIENTS IN TERTIARY CARE HOSPITAL.
}

\author{
Sheena $\mathbf{P}^{1}$, Dr. Indira Arumugam ${ }^{2}$, N.Subhashini ${ }^{3}$ \\ 1. M.Sc Nursing, Department of Medical Surgical Nursing, Narayana College of Nursing. \\ 2. Principal, Narayana College of Nursing, Chintha reddy palem, Nellore. \\ 3. Asst.professor, Sree Narayana Nursing College, Nellore, Andhra Pradesh, INDIA.
}

\section{Manuscript Info}

\section{Manuscript History:}

Received: 14 April 2016

Final Accepted: 19 May 2016

Published Online: June 2016

Key words:

Compliance, Lifestyle Modification,

Complications, Hypertensive

Patients..

*Corresponding Author

N.Subhashini.

\begin{abstract}
Background:- Hypertension is the leading cause of cardiovascular disease worldwide. Recent reports In India reveals that Hypertension is a major risk factor for cardio vascular disease that killed 2.7 million people in 2004 and will results in the death of over 4 million people by 2030. If these people take effective lifestyle modification measures along with compliance to medication they can prevent severe complications of this disease.
\end{abstract}

Materials And Methods:- The present cross sectional descriptive study was conducted with an aim to identify the Compliance Regarding Life Style Modifications in Preventing Complications among hypertensive patients.100 samples were included and data collected by interview method.

Results:- The study results revealed that majority $63 \%$ of samples had non compliance on life style modification for hypertension and $37 \%$ of samples had compliance on life style modifications for hypertension.

Conclusion:- The study concluded that there is an emerging need for educating the population regarding the need for prompt and effective life style modifications.

Copy Right,IJAR, 2016...All rights reserved.

\section{Introduction:-}

Hypertension is a silent killer disease since it generally has no symptoms until serious complications develops in the person. Globally 32 million people died due to non-communicable diseases and over half of these (16.7 million) died due to CVD. Recent reports shows in India steady increase in hypertension prevalence over the last 50 years. It comprises $25 \%$ urban population and $10 \%$ of rural populations are suffering with hypertension in India. Compliance in regard with life style modifications is defined and characterized in regard to the recommended changes in life style and attendance to medical appointment .It expresses patient's agreement with recommendations and participates in decisions related to health, (British medical bulletin on management of essential June 2010).

Recent study conducted by (Arumugam Indira, 2015) on prevalence of pre hypertension among the adults in coastal and non coastal areas of Nellore district. Andhrapradesh. The study results shown that regarding pre hypertension in SBP, in coastal areas $1129(45.16 \%)$ and in non coastal areas 971(38.84\%). The results indicate that there is high prevalence of pre hypertension in coastal areas than non coastal areas and also the incidence are shooting up very rapidly which require prompt preventive measures at various levels. 
Hypertension can be controlled by drug therapy, diet therapy, physical activity, periodic evaluation and other relevant life style changes but it is a chronic condition that cannot be cured. So it is not always possible to keep the patient in the hospital, hence forth the patient must adopt healthy life style changes to prevent further consequences. David.A.Calboun, MD (Chair person of Guide line writing committee) has reported that the patients need to recognize that the importance of blood pressure control is by the combined approach of life style modifications are effective and thereby preventing further occurrence of complications.

As stated by Alumni Association of Mayo Clinic (2009), Life style plays a vital role in treating blood pressure that is if a person is successful in reduction of blood pressure by healthy lifestyle modifications they can even reduce the need for medications.

Considering the increasing magnitude of the population affected by hypertension is an important challenge for the nurses in all health care settings. From the available literature reviewed it was found that hypertension is a deliberating condition responsible for high morbidity and compliance to life style modification is an effective measure to prevent and control the disease progression leading to chronic conditions.

Hence the researcher felt the need to investigate and to assess the compliance in view of life style modifications which helps in preventing complications thus improving quality of life among hypertensive clients.

\section{Objectives:-}

* To assess the compliance regarding lifestyle modifications in preventing complications among hypertensive patients.

* To associate the compliance regarding lifestyle modifications with selected socio-demographic variables.

* To formulate instructional module regarding compliance to life style modifications for preventing complications among hypertensive patients.

\section{Materials anad methods:-}

Cross sectional descriptive design was selected for identifying the compliance to life style modifications for preventing complications among hypertensive patients in Narayana Medical College Hospital, Nellore. 100 hypertensive patients were selected by using Non Probability Convenience sampling technique. After obtaining ethical clearance data was collected by using the interview method.

\section{Inclusion Criteria:-}

* Hypertensive patients admitted in NMCH and who are attending outpatient departments.

* Hypertensive patients who are interested to participate in the study at the time of data collection.

\section{Exclusion criteria:-}

* Hypertensive patients with other disorders like D.M, Asthma and with complications.

* Hypertensive patients who are not willing to participate and not available at the time of data collection

\section{Description of the tool:-}

The tool consists of two parts

Part 1:- Deals with demographic includes age, gender, type of family, education, family history of hypertension, previous hospitalization, diet, duration of hypertension, occupation, family income, leisure activities .

Part 2:- It deals with a set of questionnaires on components of smoking, alcohol consumption, sodium diet, exercises, and weight status and drug regimen.

\section{Data collection procedure}

The data collection is done for a period of 6 weeks. Permission to conduct study was obtained from the Medical Superintendent, Nursing Superintendent, Departmental Co-guide and Ethical Committee in Narayana Medical College Hospital, Nellore. The samples were informed by the investigator about the nature and purpose of the study and consent was obtained. 


\section{Results:-}

The present study was conducted to assess the compliance regarding life style modifications in preventing complications among hypertensive patients. Socio demographic characteristics of the hypertensive patients along with the compliance regarding life style modifications in preventing complications are presented in tabulated forms.

Socio demographic data:-

Section I:- Frequency and percentage distribution of demographic variables among hypertensive patients.

\begin{tabular}{|c|c|c|c|}
\hline Sl.no & Demographic variables & Frequency & Percentage \\
\hline 1 & $\begin{array}{l}\text { Age } \\
\text { a) } 26-35 \text { years } \\
\text { b) } 36-75 \text { years }\end{array}$ & $\begin{array}{l}36 \\
64 \\
\end{array}$ & $\begin{array}{l}36 \% \\
64 \% \\
\end{array}$ \\
\hline 2. & $\begin{array}{l}\text { Gender } \\
\text { a)Male } \\
\text { b)Female }\end{array}$ & $\begin{array}{l}59 \\
41\end{array}$ & $\begin{array}{l}59 \% \\
41 \%\end{array}$ \\
\hline 3. & $\begin{array}{l}\text { Type of family } \\
\text { a)Joint family } \\
\text { b)Nuclear family } \\
\text { c)Extended family }\end{array}$ & $\begin{array}{l}42 \\
32 \\
26\end{array}$ & $\begin{array}{l}42 \% \\
32 \% \\
26 \%\end{array}$ \\
\hline 4 & $\begin{array}{l}\text { Education } \\
\text { a)illiterate } \\
\text { b)primary education } \\
\text { c)secondary education } \\
\text { d)Graduate }\end{array}$ & $\begin{array}{l}41 \\
26 \\
20 \\
13\end{array}$ & $\begin{array}{l}41 \% \\
26 \% \\
20 \% \\
13 \%\end{array}$ \\
\hline 5. & $\begin{array}{l}\text { Occupation } \\
\text { a) Unemployement } \\
\text { b) Daily Wage } \\
\text { c)Government Employee } \\
\text { d)Business }\end{array}$ & $\begin{array}{l}29 \\
36 \\
16 \\
19 \\
\end{array}$ & $\begin{array}{l}29 \% \\
36 \% \\
16 \% \\
19 \% \\
\end{array}$ \\
\hline 6. & $\begin{array}{l}\text { Family income per month } \\
\text { a)Rs. } 1500-3000 \\
\text { b)Rs. } 3001-5000 \\
\text { c)Rs. } 5001 \text { and above }\end{array}$ & $\begin{array}{l}46 \\
29 \\
25\end{array}$ & $\begin{array}{l}46 \% \\
29 \% \\
25 \%\end{array}$ \\
\hline 7. & $\begin{array}{l}\text { Family history of hypertension } \\
\text { a)Yes } \\
\text { b)No }\end{array}$ & $\begin{array}{l}48 \\
52\end{array}$ & $\begin{array}{l}48 \% \\
52 \%\end{array}$ \\
\hline 8. & $\begin{array}{l}\text { Previous hospitalization } \\
\text { a)Yes } \\
\text { b)No }\end{array}$ & $\begin{array}{l}53 \\
47\end{array}$ & $\begin{array}{l}53 \% \\
47 \%\end{array}$ \\
\hline 9. & $\begin{array}{l}\text { Diet } \\
\text { a) Vegetarian } \\
\text { b) Non vegetarian }\end{array}$ & $\begin{array}{l}14 \\
86 \\
\end{array}$ & $\begin{array}{l}14 \% \\
86 \%\end{array}$ \\
\hline 10. & $\begin{array}{l}\text { Duration of hypertension } \\
\text { a) } 0-12 \text { months } \\
\text { b) } 13-24 \text { months } \\
\text { c) } 25-36 \text { months } \\
\text { d) } 37 \text { months and more }\end{array}$ & $\begin{array}{l}30 \\
28 \\
17 \\
15 \\
\end{array}$ & $\begin{array}{l}30 \% \\
28 \% \\
17 \% \\
15 \%\end{array}$ \\
\hline 11 & $\begin{array}{l}\text { Leisure activities } \\
\text { a)Watching TV } \\
\text { b)Exercise } \\
\text { c)Gardening } \\
\text { d)Others }\end{array}$ & $\begin{array}{l}48 \\
13 \\
14 \\
25\end{array}$ & $\begin{array}{l}48 \% \\
13 \% \\
14 \% \\
25 \% \\
\end{array}$ \\
\hline
\end{tabular}


Section II:- percentage distribution of sample according to compliance status.

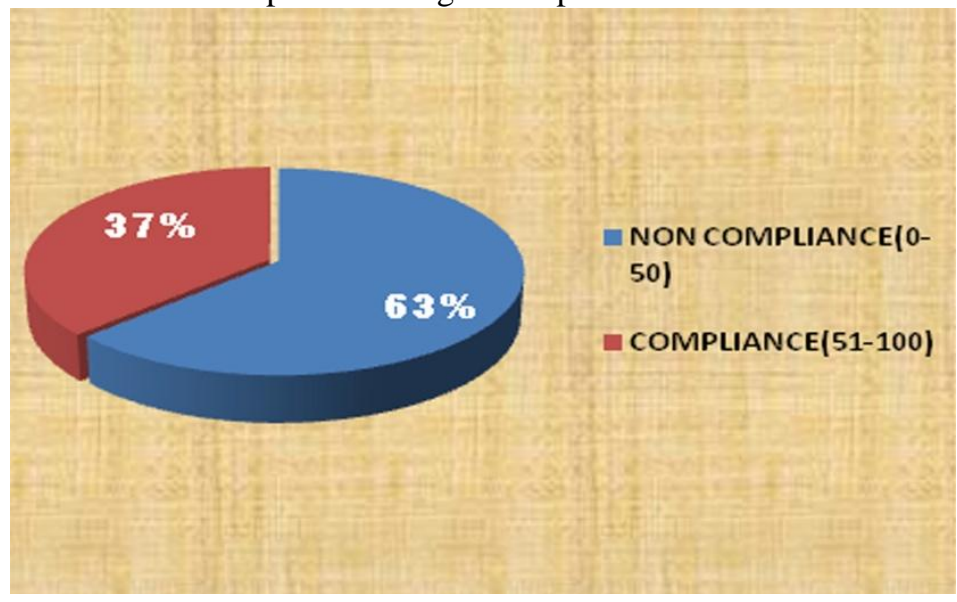

Section III:- Association between compliance regarding life style modifications and socio demographic variables of hypertensive patients.

There is a significant association was found between age, duration of hypertension and compliance levels of hypertensive patients. Remaining socio demographic variables has shown non significant association with the compliance regarding life style modification of hypertensive patients.

\section{Discussion:-}

Hypertension is a leading cause of cardiovascular disease mortality rate. Uncontrolled hypertension is caused mainly by non adherence to the hypertensive drugs and life style modifications. The present study was aims to identify the compliance regarding life style modification among 100 hypertensive patients attending to Narayana medical college hospital. The data was obtained by interview method. The study findings explore that majority 63 (63\%) hypertensive patients have noncompliance and $37(37 \%)$ has compliance regarding life style modifications. The results are compatible with study conducted by Nyaradzai Arster katena et al (2015) in Mazowe district, Zimbabwe and they concluded that, there was a high prevalence of non compliance with recommended lifestyle modifications.

The present study observes that, there was a relationship between age and lifestyle compliance .36-75 years hypertensive patients are more compliance with lifestyle modification (16\%) than 26-35 years. The study finding also depicts that there was a relationship between duration of hypertension and lifestyle compliance among hypertensive patients. $8 \%$ of hypertensive patients more than 3 years had more compliance to lifestyle modification when comparing with those that of shorter duration of illness.

\section{Recommendations:-}

Quasi experimental study can be done to assess the effectiveness of self instructional module on knowledge of life style modifications among hypertensive patients.

More research should be done for identifying the factors leading to non adherence to lifestyle modification.

Explorative study can be conducted for indentifying how the age and duration of illness are showing effect on the compliance among hypertensive patients.

\section{Conclusion:-}

The study findings revealed that majority of hypertensive patients are non compliance to life style modification. The researcher provided information booklet to all participant in the study. Hence there is need to conduct various educational and awareness programmes for enriching the information for preventing further complications among hypertensive patients. 


\section{References:-}

1. Arumugam Indira, k. k. (2015)., Prevalence of Pre Hypertension among the Adults Aged 20-60 Years in Coastal and Non Coastal areas. International Journal of recent scientific research, 7166-7170.

2. Brunner and suddarth's, "Text Book of Medical Surgical Nursing", 10th edition, Lippincott William and Wilkins Publications, Philadelphia, 2004, pp 854-865.

3. Donald M. Lloyd-Jones, (2009),'Novel approach for examining cardiovascular events after hypertension onset", Journal Of American Society Of Hypertension, Volume 3, Issue 5 , Pages 321-331.

4. F L Rosenfeldt, (2007),"Coenzyme Q10 in the treatment of hypertension", Journal Of Human Hypertension, 21, 297-306.

5. Greenwich, (2009)," Blood pressure control in hypertensive patients", Clinical hypertension, Aug; 11(8):43240.

6. Heymann AD, (2011),"Factors associated with hypertensive patient's compliance", Israel Medical Association Journal, Sep; 13(9):553-7.

7. Joyce M Black, "Medical surgical nursing", 6th edition, Harcourt publications, 2001, New Delhi, pp1489-1493.

8. Kantha Katari, I. A. (2015). Prevalence of hypertension among the adults in coastal and non coastal areas. International Journal of Development Research, 05 (01), 3134-3139.

9. Nyaradzai Arster katena, julita Maradzika (2015) "correlated of compliance with lifestyle modifications among hypertensive patients", International journal of health promotion and education, Jul: 53(6):315-327.

10. Peila R, (2006),"Efficacy of long term treatment of hypertension associated in reducing the risk of dementia", Stroke journal, May; 37(5):1165-1170.

11. Sharma AM, Wittschen HU, Kirch W, Pittrow D, Ritz E, Goke B, Lehnert H. High prevalence and poor control of hypertension in primary care: cross-sectional study, Journal Of Hypertension, 2004; 22; 3: 479-486.

12. Slimko ML, (2010),"Role of diets, food, and nutrients in the prevention and control of hypertension and prehypertension," Clinical Cardiology, Nov; 28(4):665-74.

13. SpenceJD , (1999), "Life style modifications to prevent and control hypertension", Canadian Medical Association Journal, 4:160, 46-50.

14. Tan EK, (2009), "Characteristics and disease control and complications of hypertensive patients ",Ann Acad Medicine Journal, Oct;38(10):850-856.

15. Wang L, (2010),"Dietary fatty acids and the risk of hypertension in middle aged and older aged women", Journal on hypertension, Oct; 56(4):598-604.

16. Zheng L, (2010),"Predictors of progression from pre hypertension to hypertension", cardiovascular prevalence and rehabilitation journal, Apr; 17(2):217-22. 